\title{
Intelektualni aspekti dugog kraja Prvog svjetskog rata i razgradnje Habsburške Monarhije*
}

\begin{abstract}
Vodeći se istraživanjima i zaključcima povjesničara Roberta Gerwartha o Prvom svjetskom ratu kao ratu koji „nije završio“, kao i nizom drugih povjesničara koji u suvremenoj historiografiji pronose ideju o ratu čiji je nemirni završetak u dužem trajanju od 1917. do 1918. godine bio tek privremen te je u narednim godinama davao povoda za daljnja razaranja i nemire, u ovom ću se radu usredotočiti na ideju „,dugog kraja“" rata i sve one posljedice koje je ostavio na zemlje srednjoistočne Europe, ponajprije na Habsburšku Monarhiju. Uvidom u relevantnu literaturu nastojat će se skicirati raznovrsni intelektualni preduvjeti koji su u kontekstu Srednje i Istočne Europe prizivali opadanje povjerenja u višestoljetne države ili imperijalne projekte, istovremeno otvarajući prostor za domišljanje novih projekata koji su imali izvorišne osnove bilo u romantičnim predodžbama o nacionalnim državama s povijesnim pravom, bilo u modernizacijskim velikim naracijama koje su proizlazile iz ideologija 19. stoljeća. Uz makroregionalni fokus, posebna pažnja bit će dakako pridana i primjerima iz hrvatske povijesti koji se mogu iščitati iz relevantne historiografske literature.
\end{abstract}

Prvi svjetski rat u vremenu obilježavanja stote obljetnice prolazi kroz neku vrstu historiografskog preporoda. Taj se preporod očituje u jačanju povjesničarskog i šireg javnog i građanskog interesa za sve aspekte povijesti razdoblja od 1914. do 1918. te na vrlo zanimljiv način ujedinjuje elemente jedne snažno revitalizirane, narativno fundamentirane niti klasične političke historije, socio-kulturnohistorijskih pristupa, povijesti svakodnevice, rekapitulacije životopisa velikih i važnih ličnosti, rata kao „mjesta sjećanja“ i memorijalizacije kroz metode javne povijesti. ${ }^{1}$ Kad razmotrimo globalne doprinose, stogodišnjica 1914. kao da je bila prigoda za reprizu - u prvom su planu najčešće bili povjesničari toliko odani naraciji koliko i analizi, poput Christophera Clarka, Seana McMeekina, Margaret MacMillan ili Gordona Martela. ${ }^{2}$ Često su ponavljali poznato ili su se nastojali postaviti prema tumačenjima Fritza Fischera i njemačke historiografije 1960-ih. Međurazdoblje 1915./1916./1917. bila je prigoda za povratak poznatim bitkama, ofenzivama,

\footnotetext{
Ovaj rad nastao je uz potporu Stipendije za izvrsnost Filozofskog fakulteta Sveučilišta u Zagrebu.

1 O isprepletenosti ovih pitanja - istovremeno ih potičući u javnoj sferi i propitujući u znanstvenoj - nadahnuto posljednih godina piše američki povjesničar Jay Winter, koji se posebno bavi odnosom Prvog svjetskog rata i kulture sjećanja. Vidi: WINTER I PROST 2005.

2 CLARK 2012; MCMEEKIN 2017; MACMILLAN 2013; MARTEL 2017.
} 
kao i povijesti Ruske revolucije. No, 1918. kao da je polučila najveći interes za nove i svježe poglede, za odmak od klasičnog i pomak prema novim pokušajima sveobuhvatnih pogleda.

Sama godina plodno je tlo za raznovrsna historijska konceptualna osmišljavanja. Prvi svjetski rat kraj je „dugog 19. stoljeća“ Erica Hobsbawma, jednako kao što predstavlja i početak „doba ekstrema“. Enzo Traverso vidi trenutak 1918. kao ključan element u vremenu „europskog građanskog rata“. ${ }^{3}$ Kako sam lapidarno utvrđuje o predodžbama o tom vremenu: „Kad razmišljamo o desetljećima između Prvog i Drugog svjetskog rata, sve je u tami. Vidimo rovove, tračnice koje vode do Auschwitz-Birkenaua pod snijegom poljske zime, oblak atomske eksplozije u Hirošimi.“4 Najpoznatija dosjetka o 1918. ona je, apokrifna, o početku „dvadesetogodišnjeg primirja“, koju je maršal Ferdinand Foch izrekao nakon potpisivanja sporazuma Versajske mirovne konferencije. Povijesni trenutak 1918., u užem i širem smislu, nudi se onima koji su dovoljno smjeli ili spretni izraziti mišljenje u sažetoj izreci ili zvučnom pojmu.

Na kraju obljetničarske revitalizacije, u godinama 2017./2018., došla je i ideja svojevrsnog „dugog kraja“ Prvog svjetskog rata. U historiografskoj zajednici, gdje se sve snažniji naglasci stavljaju na istraživanje pojmovnog ili iskustvenog preklapanja i isprepletenosti (entangled histories/histoire croisée), ${ }^{5}$ pazimo kako sve manje inzistirati na temeljitosti prijelomnice i prevrata, a sve se više pažnje posvećuje kontinuitetima i transtemporalnim, čak epohalnim trajanjima „građanskog“, „elitnog“" ,pučkog“, „popularnog“, civilizacijski sporo promjenjivog. Što je ovdje novo? Međunarodnoj historiografskoj zajednici, a među njima hrvatski kontingent nije relevantna iznimka, termin kontinuiteti/diskontinuiteti dolazi već više godina i desetljeća kao klasično oruđe ili dodatak u terminološkom instrumentariju. Dakle, novost može biti samo u trajnoj revitalizaciji već ustaljenih termina kroz unošenje inovativnijih koncepata, koji su katkada tek na razini povjesničarski „,novogovornih“ kovanica, a katkad se povezuju i s nekim metodološkim obratima. U taj procjep trajne revitalizacije u posljednje vrijeme ulazi ideja „,dugog kraja“ Rata. „ „Dugi kraj“

3 Traverso odaje priznanje Ernstu Nolteu kao rodonačelniku ovog termina, TRAVERSO 2016: $1-2$.

4 TRAVERSO 2016: 1.

5 Vidi, primjerice, novi zbornik: IVELJIĆ 2015.

6 The German Historical Institute London, organizirao je u Hannoveru u svibnju 2017. skup „The Long End of the First World War: Ruptures, Continuities and Memories“, na kojem se „, raspravi o poveznicama iskustva, historiografije i komemoracije, (...) nastojalo propitati pojmove statičnog i jasno definiranog „kraja“ Prvog svjetskog rata, koji je konstrukt u prvom redu zasnovan na europskim predodžbama."Vidi: https://www.ghil.ac.uk/the_long_end_of_the_first_world_war. $\mathrm{html}$ (posjet 20.7.2018.). Također, sredinom 2019. u Britaniji izlazi knjiga povjesničara $\overline{\mathrm{i}}$ publicista Charlesa Emmersona, naslovljena Crucible: The Long End of the Great War and the Birth of a New World, 1917-1924. „Dugi kraj“ Prvog svjetskog rata kao koncept ulazi, dakle, na velika vrata i idućih nekoliko godina bit će nam suputnik. 
kao konceptualni obrazac i istraživačko ishodište svoju polazišnu točku nalazi u zanimljivom usmjerenju suvremene historiografije - globalnom obratu ${ }^{7}$ - kojim se $\mathrm{u}$ širem interkulturalnom i komparativno-historijskom kontekstu na historiografskoj pozornici svjetske povijesti nastoji kroz šire očište skeptički propitati sve ono što znamo izvan klasičnih eurocentričnih predodžbi i povijesnih naracija koje podupiru neke predrasude poput orijentalizma, balkanizma, i drugih, sličnih „-izama“.

Također, historiografija o Srednjoj i Istočnoj Europi posljednjih je nekoliko godina na posebno izražen način postala poligon za koncepte i konceptualne pristupe. Neka od ključnih djela dolaze iz angloameričke historiografske radionice, čije sveučilišne katedre (ili, bolje, pojedinci na njima) desetljećima nastoje dešifrirati problematiku Mitteleurope, njezine neposredne okoline i „granične“ prirode. ${ }^{8}$ Realni problemi ovoga dijela svijeta u proteklim su godinama postali sve prisutniji u javnoj sferi zbog ruskih ambicija usmjerenih prema njezinim zapadnim susjedima, rasta i razvoja populističkih pokreta, jaza između bogatih i siromašnih, migracijske krize i susljedne moralne i političke panike, i tako dalje. $\mathrm{Za}$ angloamerička shvaćanja - čiji pojedini publicistički predstavnici po ocjenama i predrasudama à la Robert Kaplan (u slučaju Balkana) često ne idu dalje od konstatacije o „leopardovoj koži““ i suštinskoj neshvatljivosti prostora, takvim kakav jest, zahvaćenim vječnim netrpeljivostima i atavizmima - dragocjenima su se pokazali istraživači poput Roberta Gerwartha i Timothyja Snydera, čija su najrecentnija djela poticaj za novo promišljanje velikih problema u širokom potezu od 1914. do 1945. godine. Ovoj dvojici valja pribrojiti Omera Bartova i Erica D. Weitza, koji su uređivanjem važnog zbornika radova Shatterzone of Empires: Coexistence and Violence in the German, Habsburg, Russian, and Ottoman Borderlands iz 2013. godine dali makroregionalno čitanje povijesti istočnog i srednjoeuropskog nasilja na graničnim „lomištima“ od sredine 18. stoljeća do početka Drugog svjetskog rata u prostornom četverokutu Berlina, Beča, Moskve i Istanbula (što korespondira i s granicama Srednjoistočne Europe). Uz njih, relevantna je i opsežna studija Marka Jonesa iz 2016., Founding Weimar: Violence and the German Revolution of 1918-1919, u kojoj autor spaja ovu novu paradigmu povijesti nasilja i političke događajnice, ali na užem geografskom planu, tretirajući samo problematiku Njemačke tijekom prijelomne 1918.

\footnotetext{
Lynn Hunt u svojoj knjizi Writing History in the Global Era, tretira sadašnji trenutak popularnosti globalne historije al pari sa značajem kulturne historije krajem 1960-ih i početkom 1970-ih. Hunt između redaka daje naslutiti da važnost globalne historije mnogi današnji povjesničari još nisu osvijestili u svojim pristupima, ali se slično može postaviti pitanje koliko su neki od najvažnijih, primjerice, britanskih povjesničara 1960-ih poput A. J. P. Taylora ili Hugh TrevoraRopera, posvećivali pažnje kulturnoj historiji ili tekstovima Michela Foucaulta. Vidi: HUNT 2015.

8 Primjerice, od povjesničara koji istražuju 19. do onih koji se bave 20. stoljećem, u ovu se grupu povjesničara mogu ubrojiti Larry Wolff, Lonnie R. Johnson, Marci Shore, i mnogi drugi.
} 
Timothy Snyder 2010. godine objavio je knjigu Bloodlands: Europe Between Hitler and Stalin, a 2015. Black Earth: The Holocaust as History and Warning. Prva knjiga bavi se poviješću organiziranog nasilja u europskom pograničju, prostoru koji su dvije diktature dijelile i svaka zasebno osvajale. Druga knjiga posvećena je istraživanju ideoloških temelja Holokausta, a sam genocid ocjenjuje kao barbarsku borbu za resurse koji se mogu osvojiti u prostranstvima Istočne Europe (Black Earth crno je tlo Ukrajine koja u nacističkom imaginariju simbolizira buduću europsku žitnicu). Snyderova duologija u suštini se bavi propašću sistema vlasti i uprave utemeljene na vladavini prava ili vladavini autoriteta. Bloodlands, krvava prostranstva, predstavljaju pograničje i međugraničje usred kojeg u vakuumu vlasti ginu građani, a preživljava polusvijet, skriveni sloj društva, ta su prostranstva postojbina krijumčara, razbojnika ili profesionalnih apatrida, koji se znaju snaći i preživjeti u sistemu u kojem pravila ne postoje. Na ovim „lomištima“ imperija ruše se jake institucije i nadomještaju ih slabe institucije, što otvara prostor anarhiji i upravnoj nesređenosti.

Robert Gerwarth 2016. godine objavio je knjigu The Vanquished koja je u engleskom i američkom izdanju izašla s podnaslovom Why the First World War Failed to End (što bismo slobodnije preveli ,zašto je Prvi svjetski rat odbio završiti“), a ta je poruka svakako korisnija za potrebe ovog rada. Djelo se bavi povijesnim iskustvom pobijeđenih zemalja i imperijalnih država propalih od 1917. do 1923., od Ruske revolucije do smiraja političke situacije nakon sklapanja Ugovora iz Lausanne. U Gerwarthovu istraživačkom obzorju u ovoj se monografiji pokrivaju aspekti elitne političke povijesti, klasične povijesne događajnice, ali što je važnije, iznose se rezultati njegovog dugogodišnjeg bavljenja poviješću poslijeratnog paravojnog i vojnog nasilja unutar i između država sljedbenica četiriju carstava propalih nakon 1917. godine. Kako odgovara na pitanje o razlozima izbijanja tolike količine nasilja upravo u tom vremenu? Zaključuje da je potrebno modificirati tezu o brutalizaciji Georgea L. Mossea, susljedno najnovijoj historiografiji o toj problematici. Mosse je prezentirao ideju da su široke narodne mase, istraumatizirane iskustvom rovova i dotada neviđenim razinama ratnog nasilja, bile brutalizirane i spremne u poslijeratnom se vremenu okrenuti nasilnim metodama za postizanje svojih klasnih ili nacionalnih ciljeva, dajući virilno-militaristički naboj fašističkom i nacističkom pokretu. ${ }^{9}$ Gerwarth smatra da ova razina psihologizacije masa ne pojašnjava na zadovoljavajući način realnu poslijeratnu krizu Srednjoistočne Europe. Navodi da su poslijeratni konflikti za mnoge od sudionika bili „egzistencijalne“ i posve kaotične prirode, za razliku od ranijih organiziranih sukoba armija na bojnom polju. ${ }^{10}$ Jednostavnije rečeno, nasuprot borbi za spas „načina života“i ili ,nacionalne časti“, nakon 1917. godine,

\footnotetext{
9 MOSSE 1991: 159-181.
}

10 GERWARTH 2017: 7-8 
pred mnogim su pojedincima i klasnim ili nacionalnim skupinama stajale borbe na sam život, pred zamišljenim ili stvarnim opasnostima. ${ }^{11}$ Autor smatra da je rast nasilja spoj povijesne okolnosti propasti imperijalnih država i sukobljavanja novonastalih nacionalnih vojski i paravojnih jedinica na tek formiranim međunarodnim granicama, uz korištenje oružja preostalog iz Velikog rata. Usto, socijalne i nacionalne revolucije u razdoblju od 1917. do 1923., potaknule su izbijanje većeg broja građanskih ratova (primjerice: Rusija, Finska, Irska), koji su dotad nezabilježen broj civila izložile neposrednoj ratnoj opasnosti. ${ }^{12}$ Uvijek iznova, kad govorimo o vremenu neposredno nakon 1918., vraćamo se i na problematiku atavističke mržnje u prostoru Srednjoistočne Europe. U slučaju knjige The Vanquished, individualni su se recenzenti kritički osvrnuli na autorovu nesklonost širenju vlastitog narativa do 1990 -ih godina. ${ }^{13}$ Kad Gerwarth i pristaje na validnost sličnih historiografskih pitanja, njegovi su prijedlozi iznijansirani i metodološki promišljeni. Primjerice, u navodima iz svog članka o paravojnom nasilju od 1917. do 1923., publiciranog u tematskom broju časopisa Central European History o nasilju u propalim imperijima, Gerwarth i njegov suautor John Horne nabrajaju moguće pravce budućih istraživanja problematike nasilja u europskim poraćima: „Drugi potencijalni smjer budućih istraživanja leži u dijakronijskom uspoređivanju kulturalne demobilizacije i remobilizacije u tri poraća dvadesetog stoljeća: nakon 1918., nakon 1945. i nakon 1990. Komparativno istraživanje načina na koji su europska društva u dvadesetom stoljeću izlazila iz 'totalnih' sukoba omogućilo bi nam uvid u perpetuiranje vojnog nasilja u poslijeratnim politikama, bez obzira na vrijeme i mjesto, bilo da se radi o iznova ponavljajućim građanskim ratovima ili paravojnoj aktivnosti, a pomogla bi i u odgovaranju na pitanje zašto demobilizacija u nekim okolnostima propada, dok u nekima uspijeva." ${ }^{14} \mathrm{~S}$ druge strane, za potrebu preglednog sumiranja svojih stavova u jednom popularnom pregledu, Gerwarth ukratko zapaža da su se posljedice godina nasilja nakon Prvog svjetskog rata „osjećale i 1990-ih“, kad je Jugoslavija: „propala u brutalnom građanskom ratu tijekom kojeg su sve zaraćene strane, u pokušajima samoopravdavanja, nanovo odigrale sve užase i nepravde prve polovice stoljeća. " 15 Unatoč ovim - ipak

$\overline{11}$ Mark Jones djelomično prihvaća tezu o brutalizaciji, ali rađanje formi po kojima se taj teorijski okvir može prepoznati u njemačkom slučaju ne smješta u rovovsko iskustvo, već u iskustvo 1918./1919. i zamišljene sovjetsko-boljševičke revolucionarne opasnosti koja se nadvila nad malograđanskim njemačkim društvom. JONES 2016: 21-22.

12 GERWARTH 2017: 9-10.

13 Primjerice, $\mathrm{u}$ jednom prikazu knjige The Vanquished učitava se značenje koje autor nije ispisao: „Sablasno je uvjerljiv Gerwarthov zaključak da su mnoge od ovih pradavnih mržnji imale utjecaja i dugo nakon 1923. - u jugoslavenskim ratovima 1990-ih ili u sukobima u Ukrajini.“ Cit. prema: BURKHARDT 2017.

14 GERWARTH I HORNE 2010: 273.

15 GERWARTH 2017: 266. 
bismo ih ocijenili - retoričkim izletima, djelo The Vanquished predstavlja ključan doprinos revitalizaciji istraživanja vremena europskog poraća, bez ikakvog značajnijeg historiografskog, metodološkog i teorijskog duga teorijama o „vječnim mržnjama" europskog juga i istoka. ${ }^{16}$

Zajedničke su karakteristike Snyderova i Gerwarthova pristupa fokusiranje na prvu polovicu 20. stoljeća, na razdoblje „europskog građanskog rata“. Većina istraživača ispalih iz te „kabanice“, kao konceptualni okidač uzima događajnicu iz povijesti političkog, vojnog i paravojnog nasilja. Ta se događajnica koristi u epizodnom ili ulančanom formatu. Sada je sve veći broj povjesničara na poticaj niza projekata svoje interese usmjerio upravo na 1918., definiravši prijelomnicu u duljem vremenskom trajanju od 1917. do sredine 1920-ih, a prostorno ju smjestivši u istočna i srednjoeuropska „lomišta“, u pogranične podjele i sukobe, nedovršene i nesigurne nacionalne projekte nastale raspadom imperijalnih zajednica koje su imale izmiješane elemente autoritarne vladavine i liberalne uprave, istovremena militaristička stremljenja i vibrantno civilno društvo koje se očitovalo u umjetničkim projektima, u širokom potezu od urbane i kozmopolitske avangarde, do malograđanskog nacionalizma i šovinizma. Ovi su istraživački impulsi posebno osnaženi povijesnim trenutkom koji svojim značajem predstavlja neiscrpan izvor interesa za globalnu historiju. Iz svega ovoga vidljivo je da se stogodišnjica Prvog svjetskog rata obilježava nizom programa od 2014. do 2018. godine. Ovo je prigoda za znanstveno svođenje računa. Gdje je tu hrvatski slučaj? Hrvatska historiografija obilježava stogodišnjicu Prvog svjetskog rata izložbama, zbornicima radova, posebnim izdanjima časopisa, prijevodima bitnih stranih izdanja. ${ }^{17}$ U svakom slučaju, hrvatskoj historiografiji za jedan takav važan konstitutivni element nacionalne povijesti nedostaje temeljna monografska obrada koja bi probleme Velikog rata na području Hrvatske smjestila u sve svjetske i regionalne, kulturne, gospodarske, vojne i političke kontekste - iz kojih bismo donosili što informiranije zaključke o problematici 1918. Sama prevratna 1918. u Hrvatskoj je vrlo dobro istražena historiografska zagonetka. Međutim, vrijedi postaviti još neka pitanja koja ukazuju u kojoj bi se mjeri moglo specifični hrvatski slučaj uklopiti u makroregionalnu perspektivu, odnosno koliko hrvatska politička i društvena povijest u „dugom kraju“ Prvog svjetskog rata odgovara europskom okviru što ga je postavio Gerwarth.

Historiografija o posljednjim desetljećima i propasti Habsburške Monarhije daje nam nekoliko odgovora na pitanja o mogućnostima postavljanja takvog okvira. Ova historiografija najranije od 1980-ih pruža nove historijske perspektive

\footnotetext{
$\overline{16}$ U uvodu se Gerwarth kritički osvrće na zaslijepljenost anglo-francuskih političkih elita prema Istočnoj Europi i kratkovidnoj analitici po kojoj se radilo o „inherentno nasilnim prostorima“, cit. prema: GERWARTH 2017: 7.

17 Opsežnije o tome vidjeti: MATKOVIĆ 2017: 255-259.
} 
na život u Monarhiji, njezinu svakodevnu povijest, ali i svakodnevne strategije kojima su se pojedinci i skupine vodili radi lakšeg snalaženja u kompleksnostima austrougarskog ustroja. U širem potezu, od Garyja B. Cohena, preko Marka Cornwalla, Tare Zahre, do najnovijih studija o povijesti Monarhije iz pera Pietera Judsona i Johna Deaka, ${ }^{18}$ očituju se ta shvaćanja koja karboniziranu klasičnu naraciju pretvaraju u fluidnu povijest, gdje se nacionalni stavovi pretapaju u radove koje krasi multikulturalna perspektiva i jedna druga vrsta historiografske agende. Kako zaključuje Axel Körner: „Prečesto se povijest Monarhije pisala kao povijest 'opadanja i propasti', gdje je raspad nakon Prvog svjetskog rata određivao historiografsku agendu. Prema ovoj teleološkoj perspektivi, nacionalna šarolikost Monarhije njena je najslabija točka. Monarhija je bila osuđena na propast kao 'tamnica naroda', kako nas klišeji upućuju.“19 Dakle, prema Körneru i njegovim istomišljenicima, fokus se premješta sa sastavnih jedinica i elemenata koji su vodili raspadu Carstva, na elemente koji su Carstvo nekoliko stoljeća (pogotovo nakon Ausgleicha) držali na okupu. Agenda je izokrenuta tako da se sad čimbenik poput razgraničenja koje zanemaruje nacionalni sastav stanovništva, primjerice Hrvatske i Dalmacije, smatra ujedinjujućim čimbenikom centralne vlasti i jačanja monarhijskog zajedništva.

Povjesničar John Deak i razdoblje od 1914. do 1918. promatra u sličnom intelektualnom ključu. Vrijedi opširnije citirati njegov ironičan odmak od poznate maksime Charlesa Tillyja o tome da ,rat začinje državu i država začinje rat“. Dakle, nasuprot Tillyju: „Veliki rat razorio je habsburšku državu. Proces razaranja bio je usko povezan s novim modelima ratnog ustrojstva države i pitanjem tko je u takvom ustrojstvu donosio političke odlike. Stvarna tragedija Prvog svjetskog rata, ali i dvadesetog stoljeća, možda je habsburška priča: Veliki rat okončao je mogućnosti multinacionalizma u Europi. Umjesto promatranja rata kao posljednjeg čavla u lijesu Monarhije i vodiča novih nacija u slobodu, trebamo vidjeti koje je procese rat prekinuo. Koja je buduća multinacionalna država nestala iz vidokruga?“"20 Deakovi zaključci o ratnom razdoblju slijede matricu te ,nove historije Habsburške Monarhije“, prema kojoj je prije 1914. sposobnost administrativne evolucije mogla doskočiti svakom od pojedinačnih nacionalnih problema. Snažan naglasak u svojim radovima stavlja na rađanje civilnog društva i jačanje profesionalne birokracije koja se vodila zakonskim odredbama, a ne prohtjevima najmoćnijih pripadnika administracije. Prvi svjetski rat dokinuo je jačanje građanske klase, civilnog društva i sposobnosti administracije da nadvlada političku realnost, jer je novi čimbenik vojne uprave otvorio neku vrstu „unutarnje fronte“ između militarističkih shvaćanja i legalističkih shvaćanja klasične uprave. Sam

18 JUDSON 2018; DEAK 2015.

19 KÖRNER 2018: 517.

20 DEAK 2014: 379-380. 
tvrdi da je vojska povela „rat protiv habsburške Rechtsstaat, vladavine zakona, kao i države kakva je postojala od 1867.“21 Ovdje bismo napomenuli svoj sud da Deak ipak ponešto preoptimistično ocjenjuje administrativni razvoj Habsburške Monarhije od 1867. do 1914., pri čemu bi instruktivan bio pogled u standardni pregled hrvatske političke povijesti $\mathrm{u}$ istom razdoblju, osobito $\mathrm{u}$ turbulentnom vremenu od pada Khuena do 1914., gdje se Banska Hrvatska kao granični prostor našla u raznim diplomatskim krizama, mobilizacijama, neredima i nemirima, ustavnim krizama i atentatima. Ukratko, dok ne prihvaćamo ideju o propovijedanju „opadanja i propasti“, kako je kritički ocijenjena, nismo spremni posve pristati niti na - sad još jednu - teleološku naraciju o napretku centralne države i javne uprave ka sve boljim rješenjima za upravljanje krizom i suživotom, što je nova, iz drugih historiografija dobro znana, whigovska interpretacija.

Prema Deaku, dakle, 1918. predstavlja totalni poraz centralne vlasti i multikulturalnog civilnog društva, što je otvorilo prostor raznim ratnim i poslijeratnim nemirima, koji su skončali u svemu onome što opisuje Robert Gerwarth od 1917. do 1923. za prostor cijele Europe. Ne prihvaćajući u cjelini Deakovu interpretaciju, na hrvatskom primjeru ponudili bismo nekoliko mogućih intelektualnih i društvenih preduvjeta za situaciju u Srednjoistočnoj Europi u burnim godinama 1918. - 1923. Kako je Miroslav Hroch mogao postaviti jednu tipologiju preduvjeta za razvoj nacionalnih preporoda, koja plijeni svojom jednostavnošću, tako je vjerojatno i u ovom slučaju moguće postaviti neke preduvjete za zbivanja koja su uzrokovala prijelomni karakter 1918. Hroch je ustvrdio da postoji ,faza A (razdoblje znanstvene propagande nacionalnog razvoja), faza B (razdoblje nacionalne agitacije) $\mathrm{i}$ faza $\mathrm{C}$ (nastajanje masovnog nacionalnog pokreta). " 22 Naša je namjera ukazati na mogućnost da intelektualni preduvjeti (slični odrednicama prve dvije Hrochove faze) uvjetuju društvene preduvjete razgradnje i izgradnje država, njezinih uprava, njezinih civilnih društava, vojnih i paravojnih institucija, i tako dalje.

Djelovanje hrvatskih intelektualaca (u širem smislu Trojedne Kraljevine) u razdoblju od kraja 19. stoljeća do 1914. važno je sagledati u političkom i društvenom kontekstu. Riječ je o vremenu borbe protiv njemačkog ekspanzionizma na istok i jug Europe, kao i borbe za izmjene dualističkog uređenja. Ilustrativan je navod iz govora Ante Trumbića kojeg je održao u Dalmatinskom saboru 7. studenoga 1903., kritizirajući dualističko uređenje Monarhije: „Monarhija, koja je imala da bude stjecištem i zakloništem malenih naroda usred Evrope pod moćnim žezlom velike dinastije, iznevjerila se je svojim prvim zadacima. Pa mjesto da bude kućom slobode naroda, (...) u ovoj se monarhiji samo robuje, (...). Ali dok je narod živ, nikada se ne smije očajavati. Pa ako bi morali doći do toga da rečemo: U ovoj monarhiji nema pravice za hrvatski narod - nadodat ćemo:

21 DEAK 2018: 1106.

22 HROCH 2006: 54. 
'Ovaj je narod bio prije monarhije, pak će živjeti i poslije nje!' ${ }^{23}$ Povjerenje u monarhistički projekt prolaskom godina kopni, a jačaju centripetalne intelektualne silnice u raznim malim časopisima i bibliotekama, gdje se stavovi lakše zaoštravaju. Primjer afere Redl zanimljiv je kao studija slučaja iz 1913. godine u kojoj je posredstvom dotad slabije poznatog novinara Egona Kischa rasvijetljena afera o pukovniku koji se pokazao kao dvostruki agent u austrijskoj tajnoj službi. ${ }^{24}$ U razdoblju do 1914. sve su učestaliji glasovi koji, bilo iz nacionalne, nadnacionalne ili ideološko-klasne pozicije, postavljaju temeljna pitanja o održivosti države u trenutnom ustrojstvu - ali i pitanja o mogućnosti odumiranja države. Takvi se procesi posebno intenziviraju razvojem sindikalnog pokreta, ljevičarskih stranaka i pojedinaca koji novu socijaldemokratsku ideologiju šire među radništvom. Romantičarske predodžbe iz 19. stoljeća opstaju i migriraju u vremenu prije 1914. Krležini „byronovski“" pokušaji oko Balkanskih ratova interesantan su primjer. Općenito gledano, ratovi na Balkanu od 1912. do 1913. daju i novi impuls zamišljanju drukčijeg svijeta i drukčije državne zajednice. ${ }^{25}$ Srpski „Pijemont“ privlači pripadnike ovog novog civilnog društva, koje je sposobno misliti kontrakulturno spram prevladavajućih svjetonazora. Slovenski liječnik Ivan Oražen, koji je u Prvom balkanskom ratu sudjelovao kao pripadnik srpskog saniteta, piše svoja sjećanja o atmosferi u Sloveniji po izbijanju rata: „I onda je uzdrhtao sav slovenski sviet, pa i kod malenog slovenačkog naroda uzplamtila je visoko vatra svetog oduševljenja, koju je podpirivala iskrena želja, da bude jugoslavensko oružje pobjedonosno. Znali smo, da će se u tom krvavom ratu odlučiti sudbina južnih Slovena, razumjeli smo veličinu i ozbiljnost ovog velikog pohoda naše braće, za to i nije bilo medju Slovencima nikakvih demonstracija bez svakog značenja, nego je slovenački narod na miran, dostojan, ali za to ipak na odlučan način pokazao svoju ljubav do balkanske braće. “26 Dakle, trebalo bi dublje istražiti intelektualne preduvjete koji vode do pristajanja na rad ,protiv države“, veleizdaju, ali i rad protiv interesa vlastite Monarhije. Arnold Suppan istražio je djelovanje velikosrpskih propagandista u jeku Prvog svjetskog rata, od kojih su mnogi optuživani za veleizdaju. Njegov je zaključak da su: „Višestruke prijave, policijske istrage i sudski pretresi (...) među inteligencijom u Hrvatskoj i Slavoniji, koja je 1914. većinom bila lojalna, stvorili takvu klimu koja je rezultirala otklonom od Podunavske Monarhije. (...) načelno nacionalno-političko nepovjerenje i političko proganjanje u samoj Podunavskoj Monarhiji bitno [su]

\footnotetext{
TRUMBIĆ 1986: 53-55.

24 KISCH 1956: 257-274.

25 DESPOT 2013: 252-260. Igor Despot iscrpno nabraja sve modele i metode pomoći srpskom narodu, kao i stavove samog srpskog naroda, čije pripadnike vlasti ocjenjuju ,antidinastički raspoloženima“.
}

26 ORAŽEN 1912: 4. 
pridonijeli tome da su 29. listopada 1918. godine Hrvati i Srbi u Hrvatskom saboru raskinuli s Austrijom i Ugarskom.“27

Ličnost javnog intelektualca, književnog kritičara i publicista Milana Marjanovića, ključna je za razumijevanje nekih od gore spomenutih stavova. On je ličnost kroz čije se djelovanje može pratiti razvoj i uspon mreže tih malih časopisa, intelektualnih utočišta austro-ugarske kontrakulture u hrvatskom podneblju, civilnog društva u nastajanju. Milan Marjanović ponikao je iz tog šarolikog predratnog civilnog društva, kad je mnogo toga bilo formalno zabranjeno ili cenzurirano, ali se zapravo nije moglo ili stizalo zabraniti. Zbog dugotrajnosti svog političkog i literarnog djelovanja, zanimljivo je pratiti evoluciju njegovih stavova kako idu od negativnih prema konstruktivnima nakon 1918. godine. U ožujku 1914. u listu Narodno jedinstvo, piše svoj programatski nacionalistički osvrt: „Nacijonalizam bez oslonca u ojačanju najširih slojeva naroda i bez naprednosti čitavog javnog života, nije dovoljno savremen, ne može biti dovoljno širok, ne će moći da bude borben, a po tom ni uspješan. Demokratizam i naprednost bez nacijonalizma ostat će uvijek kozmopolitski i teorijski. (...) Ovaj nacijonalizam, koji pročišćenim hrvatstvom, srpstvom i slovenstvom vodi jugoslovjenstvu, koji jača svaku čest za cjelinu, spasava cjelini sve tekovine svake od pojedinih česti (...). Ovakova medjusobna propaganda je danas najpreči posao, jer je to najprirodniji način da se u dogledno vrijeme stvori sintetički jedinstven tipus jugoslovjenski i jer bi bilo neumjesno, a možda i opasno, već sada htjeti prejudicirati konačnoj formi i imenu.“ ${ }^{28}$ Marjanović ovdje ne „ruši“ državu zbog države same, zbog njezinog društvenog sadržaja, nego zbog forme. Nastoji ju zamijeniti sličnim paternalističkim političkim projektom, bez dubinskog socijalnog i revolucionarnog prevrata. Njegovi stavovi iz poraća pomažu ocrtati mnoge slične intelektualne projekte nacionalne obnove - a mnogi se oslanjanju i na sličnu biološku terminologiju u procesima intelektualnog domišljanja izgradnje države: „,...) čuvanje tradicija i osebina, čuvanje onoga po čemu nismo bili jedno, nije i ne smije biti mjerodavno kod prosudjivanja državne forme. Naš cilj nije i ne smije biti u prošlosti, nego u budućnosti, i nije naše da čuvamo stare diferencije, nego da provodimo novu integraciju. Mi nismo bili i nismo još posve jedinstveni narod, već smo narod koji se sada formira. Naše ujedinjenje je stvaranje, a ne vraćanje. Mi nećemo silom rezati stare grane, ali nećemo im ni nove hrane davati, da još i više divergiraju. Mi nismo protiv nasilne centralizacije za to što bi bili protiv koncentrisanja,

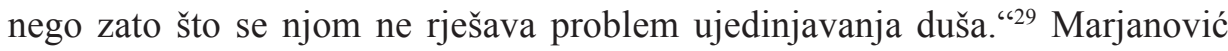
je bio kritičar ,pravničkog“ pristupa politici. Bio je pisac koji se oduševljavao

$\begin{array}{ll}27 & \text { SUPPAN 1999: 355-356. } \\ 28 & \text { MARJANOVIĆ 1914: } 1 . \\ 29 & \text { MARJANOVIĆ 1921: } 8 .\end{array}$ 
vitalizmom i idejom narodnog duha. Svojim radikalnim pristupom nastojao je taj duh i oblikovati. ${ }^{30}$

U intelektualne preduvjete razgradnje i izgradnje države ubrojili bismo i mnoštvo odluka na socijalnoj i intelektualnoj mikrorazini. Odluke koje svoj izraz nalaze u djelatnostima subverzije i otpora - otpora režimu u slučajevima nacionalističke omladine i njihovih atentata, privatnog otpora u obliku čitanja nepreporučenih autora i novinara, čime se jača njihova naklada i društveni renome, zauzimanje strana u vremenu Balkanskih ratova gdje se u hrvatskoj javnosti prate odjeci bitaka. Mnogi slični potezi, osobni životni odabiri, ne ruše državu na eklatantan način, kako to razni povjesničari prate kroz proces razvoja i rasta nacionalističkih pokreta, ali pars pro toto u hrvatskom i jugoslavenskom slučaju rastakanja ,poznatih okvira“", podrivanja i razgradnje socijalno prihvatljivog - pruža uvid u sva ona revolucionarna vrenja u produženoj 1918., pod kolektivnim nazivnikom „,bez povratka na staro“. Na Austro-Ugarsku treba pokušati primijeniti interpretativnu varijantu Broszatove ${ }^{31}$ teorije o značajkama svakodnevnog otpora režimu, kojeg se teško prati klasičnim historiografskim tragovima časopisa, novina, javnih istupa. Ovi se fenomeni mogu pratiti pažljivim izučavanjem „držanja“ javnosti u raznim situacijama, aktivnošću koja je razgranata i domišljata obavještajna služba Habsburške Monarhije pratila i bilježila na svim razinama društva. Potrebna nam je nova, dubinska povijest disidentstva u Austro-Ugarskoj do 1914., kako bismo shvatili pretpovijest prijelomne 1918. godine.

Parnjak intelektualnih preduvjeta razgradnje i izgradnje države oni su društveni. U godinama od 1918. do 1923. narod prelazi - u velikom dijelu Srednjoistočne Europe, pa i u Hrvatskoj - u centar političke arene. Širenje prava glasa na sve muškarce otvara prostor političkom populizmu čime se stvara prostor za nove društvene dogovore između onih koji biraju i onih koji su birani. ${ }^{32} \mathrm{U}$ hrvatskom slučaju, Radić seljaštvu daje politički program koji nudi samosvijest, povratak na mitske „stare pravice“, prihvatljiv društveni i ekonomski program, pravnu sigurnost i novi republikanski državni okvir. Ljevičarske stranke i komunisti u Hrvatskoj, Jugoslaviji i ostatku Srednjoistočne Europe, nakon kraha širenja revolucije 1918. godine i nekoliko neuspjelih pokušaja (Bavarska, Bela Kun u Mađarskoj), oslanjaju se na kulturne popularizatore vlastitih političkih linija - u Hrvatskoj se oslanjajući na javni rad poznatih pisaca ili novinara poput Miroslava Krleže i Augusta Cesarca.

\footnotetext{
30 ARALICA 2016: 238-239.

31 Martin Broszat, njemački povjesničar koji je 1980-ih vodio projekt o povijesti bavarske svakodnevice u nacističkom režimu, Bayern in der NS-Zeit, u kojem je vrlo široko definirao otpor vladajućem režimu, od otvorenog suprotstavljanja, do primjerice, jednostavnih i svakodnevnih odbijanja sudjelovanja u masovnim manifestacijama.

32 WEYLAND 2012: 27.
} 
Krajem Prvog svjetskog rata (nadovezujući se na Gerwartha), u austrougarskom slučaju, država počinje gubiti monopol na nasilje - javljaju se komiti i zeleni kader, oružani bjegunci i pljačkaši pretvaraju panonske prostore u nesigurna mikroratišta. Sabor je 28. listopada 1918. na široko rasprostranjenu društvenu destabilizaciju reagirao ovakvim pozivom: „Svi vojnici t. zv. zelenog kadera na teritoriju banske Hrvatske, riješavaju se svoje vojničke prisege, te se pozivlju, da se prema svojoj čovječjoj i narodnoj dužnosti odmah povrate svojim kućama.“ Nakon ovih zaključaka nastavlja se rasprava koja oslikava rapidne procese izgradnje države, od zamisli saborskih poslanika, do rezolucija koje će se provoditi na terenu: „Dr. Petričić ističe: mi smo na sudbonosnom raskršću. Prva je stvar da imademo vojsku. U zemlji se javljaju primjeri boljševizma i anarhije. Ovo naše veće ima biti početak revolucije, ali u dogovoru sa vladom. Vojsku treba riješiti zakletve.“"33 Interesantan je i navod iz izvještaja J. Luterottija iz Pule u prosincu 1918., poslan Narodnom vijeću SHS o političkoj i društvenoj situaciji u tom gradu: „Ne prodje dan, a da se nije kao javna tajna govorkalo o slučajevima nepodredjenosti (insubordinacije) na jednom ili drugom brodu. Uzaludni su svi ukazi i nalogi, pooštrena listovna cenzura, premetačine i. t. d., svatko osjeća, da nestaje upliv na momčad, te sve češće govorkaju ljudi o danima kada bi imao buknuti sveopći preokret i o svojevoljnom ukinuću tog stanja disciplinarne agonije. (...) 16. listopada (!) konstituiralo [se] narodno Vijeće u Zagrebu (...) što je značilo samo po sebi konac bivše Austro-Ugarske mornarice. Uzalud se je na brodovima komandant flote trudio raznim apelima na momčad, sjećajući ju na svoju prisegu prema vladaru (...). ${ }^{\text {‘34 }}$ Do totalne društvene revolucije nije došlo. Procesi izgradnje države nastavili su se po tradicionalnijim obrascima, ali u povijesnom trenutku odmah nakon 1918., pa sve do odlaska u ilegalu, želju za jačanjem intelektualnih i društvenih preduvjeta za rušenje postojećeg stanja na sebe je preuzela novoosnovana Komunistička partija Jugoslavije, u sličnoj situaciji kao što je bilo s lijevim strankama i u ostatku Srednjoistočne Europe. Nakon 1918. nasilje će se u Kraljevini SHS nastaviti, korištenjem paravojnih političkih organizacija (poput ORJUNE) u klasične političke svrhe, što je bilo i u skladu s europskim smjerom tog vremena.

Suprotno „novoj historiji Habsburške Monarhije“, 1918. ne ocjenjujemo kao epohalnu katastrofu niti kao burevjesnika propasti multinacionalnih i transnacionalnih stremljenja. Slom država ili slom epohe imao je svoje „dugo trajanje“ i izvorište se treba tražiti u mnoštvu intelektualnih i društvenih preduvjeta koji su prethodili tom trenutku i koji su oblikovali formule za stvaranje novih država. Ovdje su nabrojani samo neki.

A slično kao što je Robert Gerwarth skicirao moguće pravce daljnjih istraživanja

33 ŠTAMBUK-ŠKALIĆ I MATIJEVIĆ 2008: 110.

34 STULLI 1959: 484-485. 
povijesti nasilja nakon Prvog svjetskog rata, i mi se možemo zapitati koliko bi bilo korisno provesti slično istraživanje intelektualnih i društvenih preduvjeta po sličnim osnovama kao u ovom tekstu - i za druge ,granice epoha“ ili kasnija rađanja „novih svjetova“ u nastavku 20. stoljeća. Kraj 1980-ih i početak 1990-ih ima svoju bogatu historiografiju, rasutu po raznim stranama, monografijama, člancima, esejima, zbornicima - koja na neujednačene i metodološki razgranate načine odgovara na pitanja koji su to intelektualni i društveni preduvjeti propasti jednog sistema, stvaranja novog sistema i susljednog kolektivnog nasilja. Za zaključiti je da još čekamo jednu novu, metodološki osviještenu, suptilnu i izbalansiranu povijest moralnog i političkog kraha 1980-ih i izboja ratnog nasilja 1990-ih, sa svim pratećim preduvjetima koji su te procese uzrokovali.

\section{Bibliografija}

ARALICA, Višeslav. 2016. Kmet, fiškal, hajduk. Konstrukcija identiteta Hrvata 1935.1945. Zagreb: Naklada Ljevak.

BURKHARDT, Alex. 2017. The Vanquished: Why the First World War Failed to End. https://www.history.ac.uk/reviews/review/2045 (posjet 1.9.2018.).

CLARK, Christopher. 2012. The Sleepwalkers: How Europe Went to War in 1914. London: Penguin Press.

DEAK, John. 2014. The Great War and the Forgotten Realm: The Habsburg Monarchy and the First World War. The Journal of Modern History 2/86: 336-380.

DEAK, John. 2015. Forging a Multinational State: State Making in Imperial Austria from the Enlightenment to the First World War. Stanford: Stanford University Press.

DEAK, John, Jonathan E. GUMZ. 2018. How to Break a State: The Habsburg Monarchy's Internal War, 1914-1918. The American Historical Review 4/122: 1105-1136.

DESPOT, Igor. 2013. Balkanski ratovi 1912.-1913. i njihov odjek u Hrvatskoj. Zagreb: Plejada.

GERWARTH, Robert, John HORNE. 2010. The Great War and Paramilitarism in Europe, 1917-23. Central European History 3/19: 267-273.

GERWARTH, Robert. 2017. The Vanquished: Why the First World War Failed to End. New York: Farrar, Strauss and Giroux.

HROCH, Miroslav. 2006. Društveni preduvjeti nacionalnih preporoda u Europi: komparativna analiza društvenog sastava patriotskih grupa malih europskih nacija. Zagreb: Srednja Europa.

HUNT, Lynn. 2015. Writing History in the Global Era. New York: W. W. Norton \& Company.

IVELJIĆ, Iskra (ur.). 2015. The Entangled Histories of Vienna, Zagreb and Budapest $\left(18^{\text {th }}-20^{\text {th }}\right.$ century). Zagreb: FF Press. 
JONES, Mark. 2016. Founding Weimar: Violence and the German Revolution of 1918 1919. Cambridge: Cambridge University Press.

JUDSON, Pieter M. 2018. Povijest Habsburškog Carstva, Zagreb: Sandorf.

KISCH, Egon E. 1956. Sajam senzacija. Zagreb: Novinarsko izdavačko poduzeće.

KÖRNER, Axel. 2018. Beyond Nation States: New Perspectives on the Habsburg Empire. European History Quarterly 3/48: 516-533.

MACMILLAN, Margaret. 2013. The War That Ended Peace: How Europe Abandoned Peace for the First World War. London: Random House.

MARJANOVIĆ, Milan, 1914. Naše shvaćanje nacijonalne politike. Narodno jedinstvo, 28. ožujka 1914.

MARJANOVIĆ, Milan. 1921. Stara i nova politika. Zagreb: Izdanje „Slav. Tribune“.

MARTEL, Gordon. 2017. The Month that Changed the World: July 1914 and WWI. Oxford: Oxford University Press.

MATKOVIĆ, Stjepan. 2017. Devetnaesto stoljeće u hrvatskoj historiografskoj produkciji 2010. - 2015. Historijski zbornik 1/69: 225-260.

MCMEEKIN, Sean. 2017. July 1914: Countdown to War, New York 2013; The Russian Revolution: A New History. New York: Basic Books.

MOSSE, George L. 1991. Fallen Soldiers: Reshaping the Memory of the World Wars. Oxford: Oxford University Press.

ORAŽEN, Ivan. 1912. Medju ranjenom srbskom braćom. Rijeka: Naklada Medjunarodne knjižare G. Trbojević.

STULLI, Bernard. 1959. Prilozi građi za historiju 1918-e u Istri i Trstu. Vjesnik Historijskog arhiva u Rijeci 5: 463-507.

SUPPAN, Arnold. 1999. Oblikovanje nacije u građanskoj Hrvatskoj (1835.-1918.). Zagreb: Naprijed.

ŠTAMBUK-ŠKALIĆ, Marina, Zlatko MATIJEVIĆ (prir.). 2008. Narodno vijeće Slovenaca, Hrvata i Srba u Zagrebu 1918-1919. Izabrani dokumenti. Zagreb: Hrvatski državni arhiv.

TRAVERSO, Enzo. 2016. Fire and Blood: The European Civil War 1914-1945. London: Verso.

TRUMBIĆ, Ante. 1986. Izabrani spisi. Split: Književni krug.

WEYLAND, Kurt. 2012. Diffusion Waves in European Democratization: The Impact of Organizational Development. Comparative Politics 1/45: 25-45.

WINTER, Jay, Antoine PROST. 2005. The Great War in History: Debates and Controversies, 1914 to the Present. Cambridge: Cambridge University Press. 


\section{Intellectual Aspects of the Long End of the First World War and the Disintegration of the Habsburg Monarchy}

Taking an inspiration from the research of Robert Gerwarth on the First World War as a war which "failed to end", as well as from other historians who have put forward the idea of a war which had a long ending from 1917 to 1918 that was only temporary in character and gave way to further destruction and unrest in the post-war years, I shall concentrate on the idea of a "long ending" of the War and the consequences which it left for the countries of Central and Eastern Europe, primarily the Habsburg Monarchy. By looking into the relevant scholarly works, I shall attempt to outline the various intellectual preconditions which invited a lack of trust in Central and Eastern European states and imperial projects, simultaneously opening a space for designing new projects based on romantic notions of national states with historical rights, or on the grand narratives of modernisation stemming from the $19^{\text {th }}$-century ideologies. Taking up a macroregional focus, special attention will be given to examples from Croatian history which can be ascertained in the relevant historiographical works.

Prijevod sažetka: Tomislav Branđolica

Keywords: First World War, 1918, historiography, Habsburg Monarchy, Central Europe, Eastern Europe, disintegration of the state.

Ključne riječi: Prvi svjetski rat, 1918. godina, historiografija, Habsburška Monarhija, Srednja Europa, Istočna Europa, razgradnja države.

Tomislav Branđolica Filozofski fakultet Sveučilišta u Zagrebu Ivana Lučića 3, 10000 Zagreb tomislav.brandolica@gmail.com 


\section{FILOZOFSKI FAKULTET SVEUČILIŠTA U ZAGREBU \\ ZAVOD ZA HRVATSKU POVIJEST \\ INSTITUTE OF CROATIAN HISTORY \\ INSTITUT FÜR KROATISCHE GESCHICHTE}

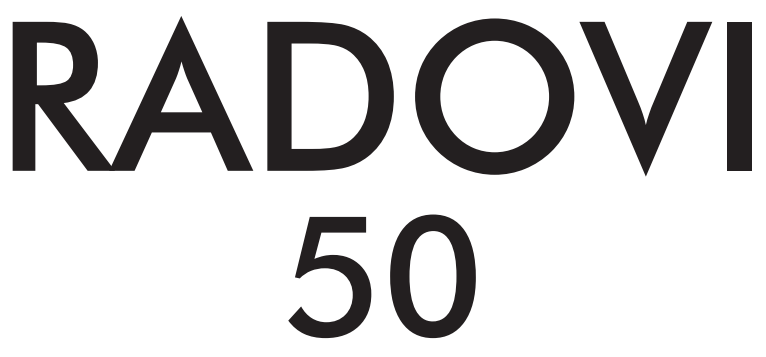

BroJ 1

ZAVOD ZA HRVATSKU POVIJEST

FILOZOFSKOGA FAKULTETA SVEUČILIŠTA U ZAGREBU

\section{FF press}

ZAGREB 2018. 


\title{
RADOVI ZAVODA ZA HRVATSKU POVIJEST FILOZOFSKOGA FAKULTETA SVEUČILIŠTA U ZAGREBU
}

\author{
Knjiga 50, broj 1
}

\author{
Izdavač / Publisher \\ Zavod za hrvatsku povijest \\ Filozofskoga fakulteta Sveučilišta u Zagrebu \\ FF-press \\ Za izdavača / For Publisher \\ Vesna Vlahović Štetić \\ Glavni urednik / Editor-in-Chief \\ Hrvoje Gračanin \\ Izvršni urednik / Executive Editor \\ Nikola Anušić \\ Uredništvo / Editorial Board
}

Bruna Kuntić-Makvić (stara povijest/ancient history), Zrinka Nikolić Jakus (srednji vijek/

medieval history), Hrvoje Petrić (rani novi vijek/early modern history), Željko Holjevac (moderna povijest/modern history), Tvrtko Jakovina (suvremena povijest/contemporary history),

Silvija Pisk (mikrohistorija i zavičajna povijest/microhistory and local history),

Zrinka Blažević (teorija i metodologija povijesti/theory and methodology of history)

Međunarodno uredničko vijeće / International Editorial Council

Denis Alimov (Sankt Peterburg), Živko Andrijašević (Nikšić), Csaba Békés (Budapest), Rajko

Bratož (Ljubljana), Snježana Buzov (Columbus, Ohio), Svetlozar Eldarov (Sofija), Toni Filiposki

(Skopje), Aleksandar Fotić (Beograd), Vladan Gavrilović (Novi Sad), Alojz Ivanišević (Wien),

Egidio Ivetić (Padova), Husnija Kamberović (Sarajevo), Karl Kaser (Graz),

Irina Ognyanova (Sofija), Géza Pálffy (Budapest), Ioan-Aurel Pop (Cluj),

Nade Proeva (Skopje), Alexios Savvides (Kalamata), Vlada Stanković (Beograd),

Ludwig Steindorff (Kiel), Peter Štih (Ljubljana)

Izvršni urednik za tuzemnu i inozemnu razmjenu /

Executive Editor for Publications Exchange

Martin Previšić

Tajnik uredništva / Editorial Board Assistant

Dejan Zadro

Adresa uredništva/Editorial Board address

Zavod za hrvatsku povijest, Filozofski fakultet Zagreb, Ivana Lučića 3, HR-10 000, Zagreb

Tel. ++385 (0)1 6120 150, 6120 158, faks ++385 (0)1 6156879

Časopis izlazi jedanput godišnje / The Journal is published once a year

Časopis je u digitalnom obliku dostupan na / The Journal in digital form is accessible at

Portal znanstvenih časopisa Republike Hrvatske „Hrčak“ http://hrcak.srce.hr/radovi-zhp

Financijska potpora za tisak časopisa / The Journal is published with the support by Ministarstvo znanosti, obrazovanja i športa Republike Hrvatske

Časopis je indeksiran u sljedećim bazama / The Journal is indexed in the following databases: Directory of Open Access Journals, EBSCO, SCOPUS, ERIH PLUS, Emerging Sources Citation Index - Web of Science 


\title{
Naslovna stranica / Title page by
}

Iva Mandić

\section{Grafičko oblikovanje i računalni slog / Graphic design and layout Marko Maraković}

\author{
Lektura / Language editors \\ Marijana Ivić (hrvatski / Croatian) \\ Dražen Nemet (engleski / English)
}

Tisak / Printed by

Tiskara Zelina, Sv. Ivan Zelina

Naklada / Issued

200 primjeraka / 200 copies

Časopis je u digitalnom obliku dostupan na Portalu znanstvenih časopisa Republike Hrvatske „Hrčak“ http://hrcak.srce.hr/radovi-zhp

The Journal is accessible in digital form at the Hrcak - Portal of scientific journals of Croatia http://hrcak.srce.hr/radovi-zhp 